\title{
Prospecting Of Culturable Acetic Acid Bacteria From Fermented Fruits
}

\author{
Vanessa Cassoni², Marney Pascoli Cereda ${ }^{1}$
}

\begin{abstract}
The flavored vinegars made from wines and fruit are y highlighted in the food gastronomy market. However it is not easy to have a good starter. It is easy to found acetic acid bacteria $(A A B)$ in the natural fermentation of fruits where they are mixed with yeasts. A medium was adapted have only AAB. For test this medium overripe fruits were fermentedby 3 days at room temperature and sampled as inoculum. Bacteria presenting AAB characteristics were identified in microscope. Samples with0.5mlwere placed into Petri dishes containing a modified Frateurmediumcomposed of agar, yeast extract, alcohol, and calcium carbonate. As fungistaticswere tested the gentian violet (1\% methylrosanilinium chloride) and nystatin water solution (10 $\mathrm{IU}$ ) both used at 0.5/1.0/1.5mlon 20mlof the mediumdirectly placed into sterile plates. Petri dishes were incubated at $25^{\circ} \mathrm{C}$ for five days and AAB colonies recognized by forming a halo. The data showed that only nystatin at dose 1.0 mlcontrolled the wild yeasts growth. Biochemical assays (Gramstaining, oxidase, catalase, indol and $\mathrm{H}_{2} \mathrm{~S}$ formation)confirmed the genus Acetobacter. The data proving that the combination of Frateur medium with 1.0 mlof water solution of nystatin $\left.10^{5} \mathrm{IU}\right) \mathrm{may}$ be a good option for isolating $A A B$ from fermenting fruit.
\end{abstract}

Keywords: Frateur medium, acetic acid bacteria, nystatin, gentian violet, vinegar.

\section{Prospecção de bactérias cultiváveis em ácido acético de frutas fermentadas}

\begin{abstract}
RESUMO
Vinagres aromáticos elaborados de vinho ou de frutas têm se destacado no mercado de alimentos especializados em gastronomia. Entretanto não é fácil conseguir inoculo de boa qualidade. É fácil encontrar bactérias do ácido acético (BAA) em frutos naturalmente fermentado onde encontram-se misturadas com leveduras. Um meio seletivo foi adaptado para isolar apenas BAA. Para testar esse meio frutas muito maduras foram fermentadas por 3 dias a temperatura ambiente e amostradas como inoculo. Bactérias que apresentavam características de BAA foram identificadas em microscópio.Alíquotas de $0.5 \mathrm{~mL}$ foram inoculadas em placas de Petricontendo meio Frateurmodificado composto de ágar, extrato de levedura, etanol e carbonato de cálcio. Como fungistaticos foram avaliados violeta de genciana ( $1 \%$ cloreto de metilrosanilina) e nistatinaem solução aquosa(10 $0^{5}$ UI) ambos a 0,5/1,0/1,5mL em 20mLdo meio que foi vertido em placas esterilizadas. As placas foram incubadas à $25^{\circ} \mathrm{C}$ por cinco dias e as colônias BAA reconhecidas pela formação de halo. Os resultados mostraram que apenas a nistatina na dose de 1,0 mL controlou o crescimento de leveduras selvagens. Ensaios bioquímico (coloração de Gram, oxidase, catalase, indole formação de $\mathrm{H}_{2} \mathrm{~S}$ ) confirmaram o gênero Acetobacter. Os resultados comprovaram que a combinação de meio Frateur com 1, mL de solução aquosa de nistatina à $10^{5} \mathrm{UI}$ ) pode ser uma boa opção para isolamento de BAA de frutas fermentadas.
\end{abstract}

Palavras chave: Meio de cultivo Frateur, bactérias acéticas, nistatina, violeta genciana, vinagre.

\footnotetext{
${ }^{1}$ Marney Pascoli Cereda- cereda@ucdb.br.
} 


\section{INTRODUCTION}

Vinegar is worldwide used as condiment and food conserve. In addition, it has been considered an indispensable complement to the human diet due to its nutritive and bio regulatory action.The production of vinegar may use as raw material several products found in rural properties,specially the ripe fruits.

Acetic acid bacteria (AAB) are the inoculum for vinegar production but are not always available in commercial or academic collections. Commercial vinegar is pasteurized and is not sure that vinegar industries may provide strains to researchers, which makes difficult the obtaining starter material for studies. The solution used all around the world is its prospection from the environment, which may provide more suitable agents to the local conditions.

Acetic bacteria, represented by the genus Acetobacter, are easily found in nature and can be obtained from fruits, flowers, bee honey, beer, and grape wine (Sengun and Karabiyikli, 2011). In the early years, AAB were classified into two main genera but nowadays twelve genera arerecognized and accommodated to the family Acetobacteracea but these strains is rather rare incommon isolation sources such as vinegar, wine, fruits and flowers(Fregapane, Rubio-Fernández and Salvador, 2006; Yamada and Yukphan, 2008; Yukphan et al., 2009, 2008).

Little is known about the ecology of the vinegar starter although there are microbiological studies focused on the production several vinegar types. The diversity and succession of microorganisms involved in fruit vinegar production, remain unstudied (Hidalgo; Mateo; Mas and Torija ,2012). The natural production of vinegar occurs in two stages. First there is the alcoholic fermentation of the sugars and then the acetylation of ethanol. The two stages may be occur simultaneously with a dynamics of microorganisms that is hard to be monitored. It is generally understood that nonSaccharomyces yeasts begin the process of spontaneous alcoholic fermentation, and $S$. cerevisiae eventually takes over and dominates the process. This has been described with grape wine although in fermentations that yield a low final alcohol content, Saccharomyces may not always appear (Chanprasartsuk et al., 2010).A high diversity of Non-Saccharomyces yeasts was only present throughout in the spontaneous fermentations (Hidalgo; Mateo; Mas and Torija (2012) and these results are not surprising because inoculation with selected yeasts reduces the growth of native yeasts (Beltran et al., 2002).

In these habitatsthe populations of yeast and $\mathrm{AAB}$ need to be were monitored by plating at various times throughout the experiment. Samples were taken three times during alcoholic fermentation: at the initiation ofthe process, at a midway point through fermentation (when the sugar was half consumed) and at the point when the residual sugar concentration was below $2 \mathrm{~g} / \mathrm{l}$. To monitor the acetificationprocess the sampling may be conducted during the initial stage, at low acidity (3\% (w/v) (Hidalgo; Mateo; Mas and Torija (2012).

If acetic acid bacteria is isolated from fruitsseveral undesirable microorganisms may be present, specially the yeast that be frequently larger than that the AAB (Sengun and Karabiyikli, 2011).

In a natural fruit fermentation is common coexistence of yeasts and acetic bacteria. Hidalgo, Mateo, Mas and Torija (2012) reported that in persimmon fermentation for vinegar naturally occurring yeast populations found to number about $10^{4}$ cells $/ \mathrm{ml}$, and most of them could be recovered by plating. Culturing from the inoculated alcoholic fermentations was more difficult because the yeast population reached a maximum number of $>10^{7}$ cells $/ \mathrm{ml}$, and only 10 e $25 \%$ were culturable. Microscopy revealed that the bacterial population was high at the beginning of acetification and decreased at the end of the process, a reduction of $99 \%$.

The ideal culture medium to isolate acetic bacteria has been discussed since 1868 (Mecca, Andreotti and Veronelli (1979). Several researchers have conducted studies in order to set the ideal culture medium to isolate acetic bacteria; thus, they discovered that the different Acetobacter species have their best development in different culture media (Krieg and Holt, 1984).

Enumeration, isolation, identification and preservation of $\mathrm{AAB}$ are not easy. Not all the media support growth of AAB equally and theyare selective forone strain to another (Gullo et al., 2006). Although there are lots of media developed forisolation and/or identification of $\mathrm{AAB}$, they mainly consistof the same ingredients with varying proportions, which causedifferent reactions on the plate. Mainly used incubationcondition for the growth of $\mathrm{AAB}$ is $30{ }^{\circ} \mathrm{C}$ for 2-5 days (Seearunruangchai et al., 2004; Yamada \& Yukphan, 2008). 
Same culture medium are simple as the described by Yamada \& Yukphan, (2008) as GY medium, composed by $2 \%$ glucose, $1 \%$ yeast extract and $2 \%$ agar um distilled water. Calcium carbonate can be added to allow a halo formation if acetic acid is formed. The culture medium GYCis described by Gullo \& Giudici, (2008) as composed by $10.0 \%$ glucose, $1.0 \%$ yeast extract, $2.0 \% \mathrm{CaCO}_{3}$ and $1.5 \%$ agar.

A variation of GYC medium is described by Gullo and Giudici, (2008) with the substitution of glucose for $2.5 \%$ of mannitol andincluding $0.5 \%$ yeast extract, $0.3 \%$ of peptone and $1.2 \%$ agar. The same culture medium with small variations is cited by Krieg and Holt(1984)have reported that the culture medium containing $1.0 \%$ yeast extract, $2 . \%$ glucose, $2.0 \%$ mannitol, $2.5 \%$ ethanol and $0.5 \%$ acetic acid yielded good results.

Most complicated culture medium uses ethanol and acetic acid. Yamada et al., (1999) describes the AE-medium composed as glucose $(0.5 \%)$, yeast extract $(0.3 \%)$ and $0.9 \%$ agar. Before the sterilization and after the sample inoculation the culture medium receives $3 \mathrm{ml}$ of absolute ethanol and $3 \mathrm{ml}$ of acetic acid. A similar culture medium is described by Zahoor et al., (2006) just as Reinforced AE-mediumby put more glucose (4\%) and yeast extract $(1.0 \%)$ and with the addition of $1 \%$ peptone, $0.15 \%$ citric acid, 2\%(v/v)ethanol, $1 \%$ (v/v)acetic acid and $0.34 \% \mathrm{Na}_{2} \mathrm{HPO}_{4} 7 \mathrm{H}_{2} \mathrm{O}$.

In 1898, researchers proved that Acetobacter species such as $A$. xylinum and $A$. rancens cannot grow in an acetic acid-ethanol mediumbut may present a good development when glucose, sucrose, mannitol or glycerol are added to the culture medium. Some years later, in 1950, researchers elucidated that the species $A$. aceti requires culture medium containing ethanol, distilled water and phosphates. Other studies with different Acetobacter species were performed to set the best culture medium (Mecca, Andreotti and Veronelli, 1979).

Although vinegar production is a growing commercial activity due to the appreciation of gourmet vinegars in the Brazilian market, the literature on the isolation of acetic bacteria for Brazilian fruits is scarce.

According to Fregapane, Rubio-Fernández and Salvador, (2001) the Frateurmedium arecapable of providing development for all strains of the genus Acetobacter. The Frateur medium is a variation of GY mediumalso composed of $1 \%$ yeast extractand $2.0 \%$ agar in distilled water, with de addition of $2.0 \% \mathrm{CaCO}_{3}$, with $\mathrm{pH}$ adjusted between 6.0 and 7.0. After the sterilization 2.0\% ethanol is added. The same authors also indicate that the best carbon sources for Acetobacter growth are ethanol, glycerol and lactate. Amino acids alone cannot be used as source of nitrogen and carbon.

Due to difficulties in isolation the number of $A A B$ recovered on plates were ever two or three orders of magnitude lower than what was observed by microscopy. The highly acidic conditions at the middle and late stages of acetification suggest that most of the bacteria present were $\mathrm{AAB}$, despite the fact that we were unable to differentiate them by microscopy (Hidalgo, Mateo, Mas and Torija (2012).

$\mathrm{AAB}$ are well known for the ability to oxidize the sugars andalcohols, resulting an accumulation of organic acids as final products, but a considerable number of $\mathrm{AAB}$ can oxidize alcohols intosugars, mannitol into fructose, sorbitol into sorbose or erythritolinto erythrulose (Gonzales, 2005).The main physiologicaldifference between the $\mathrm{AAB}$ genera was that Acetobactersp oxidized ethanol into acetic acidand, subsequently, completed the oxidation of acetic acid intowater and $\mathrm{CO}_{2}$ (Gonzales, 2005).Direct oxidation metabolism pathwayworks only in the presence of $>15 \mathrm{mM}$ glucose in the culturemedium (Weenk, Olijve and Harder, 1984).

In 1953,A acetiwas proven incapable of growing in a medium containing ethanol, mineral, and ammonia and nitrogen salts but no acetic acid, acetateor glucose, justifying that such compounds stimulate A. acetigrowth. The authors suggested that the presence of a reducing sugar is necessary to start the growth of acetic bacteria, which probably use ethanol as an additional source of carbon and energy by oxidizingit to acetic acid (Mecca, Andreotti and Veronelli, 1979).

The AAB isolationcan mayallow starters more adapted to local conditions than the agents obtained in commercial or academiccollections.

In sub-Saharan Africa, the vinegar used as food condiment is obtained from the dilution of acetic acidor imported from Europe, and the artisanal production is not common. Thus, researchers developed studies to isolate acetic bacteria from mangoanddolo, a local beer, and then tested theirabilityto adapting to high temperaturesin order to produce vinegar. In Senegal and Burkina Faso regionsthe temperature is constantly high, usually above $30^{\circ} \mathrm{C}$. The ideal temperature for the good 
growth of acetic bacteria is known to be around $25^{\circ} \mathrm{C}$. Of 17 strains, two were selected for presenting thermo tolerant properties, and vinegar of $6 \%$ acidity could be obtained by the slow process (Krieg and Holt,1984). Thermo resistant properties of AAB isolated from tropical productsof Sub-Saharan Africa were studied for its advantages of thesestrains were reported as the considerable reduction of the coolingwater expenses and the availability of the strains for traditionalvinegar fermentation (Ndoye et al., 2006).

Once isolated microorganisms is necessary to confirm that this is AAB and specifically, Acetobacter aceti.

Sengun and Karabiyikli, (2011) reports the Acetobacter spp characterizationas flagellation type peritrich, with oxidation of ethanol to acetic acid, and then aceticacid and lactate to $\mathrm{CO}_{2}$ and $\mathrm{H}_{2} \mathrm{O}$. Growth on $0.35 \%$ acetic acidby adding or containing in the medium. Do not growth or grows weakly in methanolD-mannitol and $30 \%$ Dglucose. Do not produces cellulose and the production of levan-like mucous substance from sucrose and ketogenesis (dihydroxyacetone) from glycerol is variable. Do not fix molecular nitrogen. The acid production fromD-Mannitol and Glycerol is variable but do not produces acid from Raffinose. The cellular fatty acid type is C18:1and the ubiquinone type is Q-9. The DNA base composition ( $\mathrm{mol} \% \mathrm{G}+\mathrm{C}$ ) is 52-60.

Glucose Yeast Extract $\mathrm{CaCO}_{3}$ Medium (GYC) was proposed as a medium that enabled most strains to berecovered in traditional vinegars (Gullo et al., 2006). Environment of the isolates is also important for selecting the isolation of suitablemedia. It is reported that isolates from cider or wine vinegarfermentations grew readily in Reinforced AE-Medium (ERAMedium) while AEMedium proved most suitable for the cultivationof strains isolated from spirit vinegar fermentations (Sokollek et al.,1998).

Hidalgo, Mateo, Mas and Torija (2012) were collected a total of $270 \mathrm{AAB}$ isolates during these persimmon acetification by the traditional vinegar fabrication. Most of colonies produced a clear halo around when plated on media containing $\mathrm{CaCO}_{3}$. All halo-forming colonies were Gram negative and catalase positive, which confirmed they were $\mathrm{AAB}$.

In a liquid medium such as wine with high alcohol content, the presence of free $\mathrm{SO}_{2}$ and the low availability of oxygen subjectthe microorganisms to serious stress and they probably need somerecovery before they can grow on a solid medium with a differentcarbon source (Millet and Lonvaud-Funel, 2000). Rapid method for total, viable and non-viable AAB determinationwas developed by Baena-Ruano et al. (2006) as a possibleoption, using the direct counting in a Neubauer chamber as well asan epifluorescence staining technique, using the live/dead BacLightBacterial Viability Kit. The advantagesof this method reported as follows: (i) it is a reliable, rapid,easy and yields both viable and total bacteria in only one step, (ii)samples are easy to prepare and easy to differentiate because of thehigh degree of contrast between the green color of the viablebacteria and the red color of the dead cells, (iii) BackLight stain doesnot produce background fluorescence.

Few ecological studies have analyzed the main AAB speciesinvolved in the process, while all studies have been conducted withcultivable strains only. The availability of a reliable and fast techniquefor $\mathrm{AAB}$ enumeration is very useful in the food industry, inwhich $\mathrm{AAB}$ are used as biotechnological agents or in which AABmay spoil food product (Torija, Mateo, Guillamon, Mas, 2010).

Yamada et al. (1999)were isolatedsixty-four of $\mathrm{AAB}$ from Indonesian sources such as fruits, flowers andfermented foods. AAB were also isolated from fruitscollected in Thailand. Isolates, belong to A. pasteurianus were foundin fruits of apple, banana, grape, guava, jack fruit, jujube, kaffir lime,langsat, longkong, longan, mango, mangosteen, orange, papaya,peach, pineapple, passion fruit, rose apple, rambutan, rakam, sapodilla,star gooseberry, strawberry, sugar apple, tamarind, watermelon, tomato and palm juice, while Acetobacter orientalis and Gluconacetobacter liquefaciens were found in star fruits and palmjuice, respectively (Seearunruangchai et al., 2004).

The use of substances inhibiting the yeasts in isolation and less common in the literature.Hidalgo, Mateo, Mas and Torija (2012) describes isolation ofAABby plating samples on GYC mediumsupplemented with natamicine (100 $\mathrm{mg} / \mathrm{l})$.

Others antifungal agents are cited in the literature as gentian violet is the common name of the compound methylrosaniline chloride has antifungal, although it is used as dye. Fungicidal agents, such as cetylpiridinium chloride, 
hexachlorophene, iodine (in dye form), potassium permanganate, rubiazol, thimerosal, triclosan, and gentian violet, were evaluated for six Candida species (Jarvis ,1995).

Damjanovict et al., (1993) reported control of candidiasis with daily doses of 1 mlof nystatin (100 $000 \mathrm{IU})$. Another study describes the use of nystatin as an inhibitor of the yeast. Johnson, Taylor and Held (1989) cited nystatin is in culture isolation of Candida spp in dose from 200,000 units, 400,000 units compared with placebo). Both dosages were shown to be effective in significantlyreducing or eliminating the Candida organism during active therapy.

The aim of this study was to test a culture medium for acetic acid bacteria isolation in natural fermentation of tropical fruits by using gentian violet and nystatin as yeasts inhibitors.

\section{MATERIAL AND METHODS}

\section{The inoculum}

Mixed ripe fruits (pineapple, banana and orange) were ground and kept in covered containersat 30 ${ }^{\circ} \mathrm{C}$ for as described by Seearunruangchai et al., (2004) and Yamada \& Yukphan, (2008).After $24 \mathrm{~h}$,the fruits started to present alcoholic fermentation, followed by anevident change to the acetic fermentation process. Samples from the formed fermented liquid were collected, observed under an optical microscope andstained with methylene blue as vital dye. The Gram was used to prove the presence of typical bacteria. This fermented fruit liquid $(0.1 \mathrm{ml})$ was used as inoculum presenting acetic bacteria was added in triplicate to plates containing solidified Frateur medium.

\section{Culture medium}

To isolate Acetobacter spit was used theselective culture medium was that of Frateur(Table 1)according to Bergey's Manual of Systematic Bacteriology from Krieg and Holt (1984).

Table 1 - Frateur Medium

\begin{tabular}{ll}
\hline Components & Frateur \\
\hline Yeast Extract, $\mathrm{g} \mathrm{l}^{-1}$ & 10 \\
Agar, $\mathrm{g} \mathrm{l}^{-1}$ & 20 \\
Calcium carbonate, $\mathrm{g} \mathrm{l}^{-1}$ & 20 \\
Ethanol, g ${ }^{-1}$ & 20 \\
Distilled Water, $\mathrm{ml}$ & 1000 \\
\hline
\end{tabular}

Source:Holt and Krieg, (1984)

Acetic bacteria were identified based on a transparent halo around colonies, a result of $\mathrm{CaCO}_{3}$ solubilization by the produced acids. Yeast extract was used as source of vitamin, and nicotinic acid and ethylic alcohol as sources of carbon.

To inhibit yeasts, two agents were evaluated: nystatin andgentian violet. Hydro alcoholicnystatin solution $\left(10^{5} \mathrm{UI} / \mathrm{ml}\right)$ was added at the following Frateur medium in the concentrations $\left(\mathrm{mll}^{-1}\right) 0.0$, $0.5,1.0$ and 1.5 to each $20 \mathrm{ml}$ medium. Commercial gentian violet $\left(10 \mathrm{mg} \mathrm{ml}^{-1}\right)$ was added at the following Frateur medium concentrations $\left(\mathrm{ml}^{-1}\right)$ : $0.0,0.5,1.0$ and1.5. Both substances were added after the medium sterilization 1.5 pounds/15 minutes.

The inverted plates were incubated at $25^{\circ} \mathrm{C}$ and after five days colonies were collected for observation under an optical microscope. Colonies presenting a transparent halowere streakedfor purity verification. Colonies presenting the same morphology were transferred again to Frateur medium, always by streaking, in order to maintain the isolated strain and multiply it. The isolated strains were kept at $4^{\circ} \mathrm{C}$ and subjected to biochemical evaluationsin triplicate, such as Gram 's Method, besides assays for oxidase, catalase andindoland $\mathrm{H}_{2} \mathrm{~S}$ formation, to identify the genus of the isolated bacteria (FERRAZZA et al., 2005).

\section{RESULTS AND DISCUSSION}

To obtain acetic inoculum from natural fermentation was based on the fact that vinegarproducingstarter microorganisms are not easily available in the marketeither because they are part of commercial procedures in companies or because there are scarce studies on this theme.

The use of the liquid from fermented fruit helps to reduce the amount of glucose that is related by Gullo \&Giudici,(2008) may inhibit the growth of $\mathrm{AAB}$.

The $\mathrm{pH}$ values of fermented fruits were near 6.0. As Gonzales et al.,(2006) the optimumfor the growth of $\mathrm{AAB}$ is 5e6.5 while theycan grow at lower $\mathrm{pH}$ values between 3.0 and 4.0 (Holt, Krieg, Sneath,Staley and Williams, 1994). This $\mathrm{pH}$ values is near the natural $\mathrm{pH}$ of the fermented fruits

This method may be evaluated by the great majority of $\mathrm{AAB}$ at the optical microscope analysis of the liquid obtained from fermented tropical fruits indicated microorganisms presenting morphological characteristics typical of acetic bacteria in mixture with yeasts and others. 
$\mathrm{AAB}$ have traditionally been enumerated by quantifying viablecolonies by plating in solid culture media(Gullo, Caggia, De Vero, \& Giudici, 2006). Several media were used for isolation and methods based onphysiological abilities were used for the $\mathrm{AAB}$ identification. There are some limitations for methods based on plating such as time requirement,and inability to detect viable but noncultivable (VBNC) cells. Toovercome these disadvantages of culturing, new techniques havebeen developed using molecular approaches (Gonzalez, Guillamon,Mas, \& Poblet, 2006).

If molecular approaches is not available is possible to use specific mediums to inhibit the yeasts growth, which present good development under the same conditions as those for AAB. In this paper gentian violet and nystatin were evaluated. Although mentioned in literature, in the present study the yeasts found in the fermented fruits did not have their growth inhibited by the gentian violet added to the Frateur culture medium at any one of the three tested concentrations $(0.5 / 1.0 / 1.5$ mlfor $20 \mathrm{ml}$ ). Halo was also not visible (Figure 1 A). The acid formed by acetic bacteria dissolved the calcium carbonate and could be noticed due to the coloration change at the site of acid production.

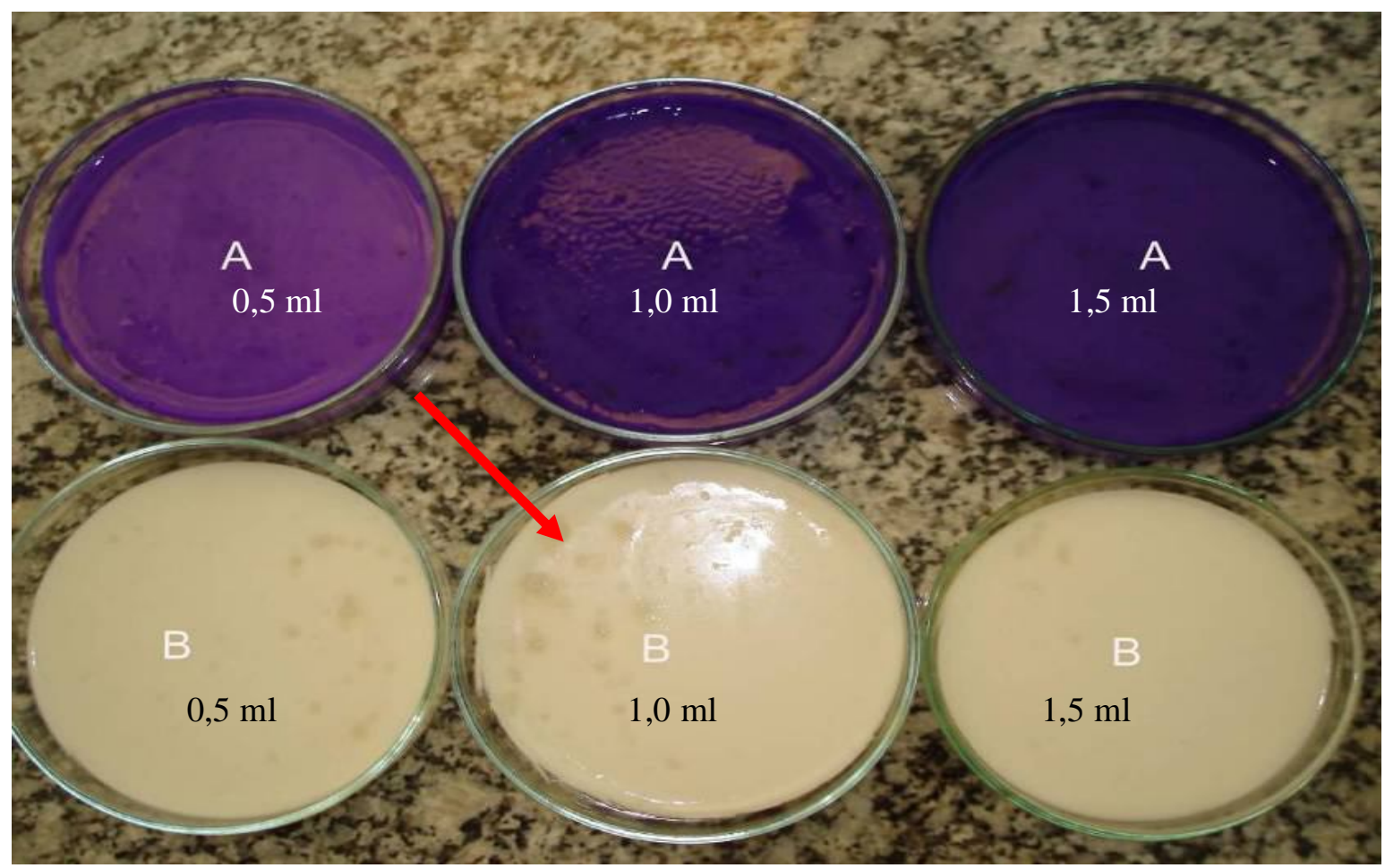

Figure 1 - Growth in Petri dishes plates with modified Frateur medium containing yeast inhibitors: gentian violet (A) and nystatin (B).

When $0.5 \mathrm{ml}$ nystatin aqueous solution at the concentration of $10^{5} \mathrm{IU}$ was used in $20 \mathrm{ml}$ medium in a Petri dish was there possible to see a partial inhibition, with weak yeast growth(Figure 2). However, 1.0 and $1.5 \mathrm{ml}$ proportions per plate completely restricted yeast growth, allowing the development of visually homogeneous colonies of acetic bacteria with a transparent halo formation
The halo (see arrow) corresponding to the beginning of the reaction involving the acid formed by acetic bacteria and calcium carbonate is shown in Figure in Petri dishes added with nystatin (Figure 1B). The halo formation that is one of the basic characteristicsthat associates a given colony to the $\mathrm{AAB}$ group(Cleenwerck and de Vos, 2008) and in general, AAB belonging to the genus Acetobacter have beenfound more frequently founded (Camu et al., 2007). Hidalgo, 
Mateo, Mas and Torija (2012) describes colonies with a halo around confirmed as $\mathrm{AAB}$ isolation when were subjectedto Gram staining and the catalase test. The authors founded 45 colonies with these characteristics from persimmon fermented for vinegar production.

In this study the microorganisms collected from the colonies with halo formation in the modified Frateur medium showed negative Gram staining (Figure 2) compatible with AAB characteristics. The selected colonies had rod-shaped Gramnegative bacteria and pale colonies surrounded by a transparent halo due to their reaction with calcium carbonate. In addition to the tests for methodology certification, the performed biochemical assays yielded the following results: negative oxidase, positive catalase, no $\mathrm{H}_{2} \mathrm{~S}$ and indol formation, and no gelatinous liquefaction. Such morphological and biochemical characteristics agree with the description of Acetobactersp genus mentioned in literature (FREGAPANE; RUBIO-FERNÁNDEZ and SALVADOR, 2001).Acetic acid bacteria (AAB) are gram-negative or gram-variable,aerobic, non-spore forming, ellipsoidal to rod-shaped cells that canoccur single, in pairs or chains. Their sizes vary between $0.4 \mathrm{e} 1$ mmwide and $0.8 \mathrm{e} 4.5 \mathrm{~mm}$ long. They are catalase positive and oxidasenegative. $\mathrm{AAB}$ are heterogeneous assemble,comprising both peritrichously and polarly flagellated organisms(Gonzales et al., 2006).

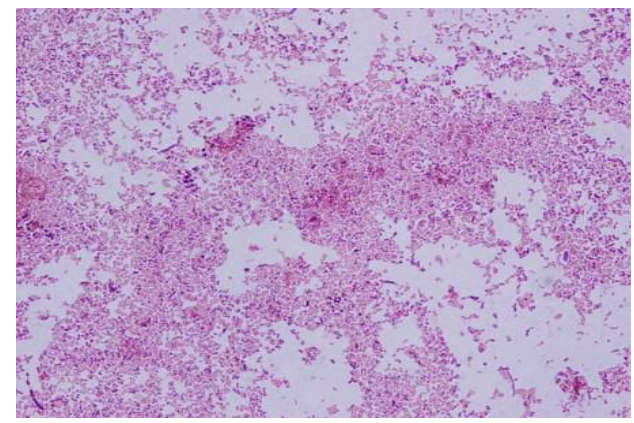

Figure 2 -Bacteria with negative Gram coloration isolated in the halo formation colonies in modified Frateur medium, using nystatin as yeast inhibitor (1000 times magnification).

The taxonomy of $\mathrm{AAB}$ has not been fully established yet andrearrangements of the group are still in progress. The reasons forthis taxonomic uncertainty are both due to the limited knowledgeof the $\mathrm{AAB}$ phylogenesis and isolation, identification and preservationdifficulties of these bacterial strains (De Vero \& Giudici,2008).

The identification of the isolated strains only by the colony morphology and biochemical test of cells is not secure, but by using a medium with high selectivity it will possible to provide a large number of isolates without much difficulty. It is probable that among this high number of coloniesit will possible toisolate many strains of Acetobacteracetiand some of them may showa good performance.

\section{CONCLUSION}

Frateurmedium adapted with yeast extract and added of $1.0 \mathrm{ml}$ nystatin perPetriplate atthe concentration of $10^{5} \mathrm{IU}$ was efficient for the growth and isolate of acetic bacteriaand the inhibition of yeast growth at $25^{\circ} \mathrm{C}$.

\section{ACKNOWLEDGEMENTS}

The authors thank the CAPES Brazilian Coordination for the Improvement of Higher Education Personnel) and CNPQ (National Council for Scientific and Technological Development) for financial support.

\section{REFERENCES}

BAENA-RUANO, S, JIMENEZ-OT, C, SANTOS-DUENAS, IM, CANTEROMORENO, D, BARJA, F, GARCIA-GARCIA, I, Rapid method for total, viable and non-viable aceticacid bacteria determination during acetification process. Process Biochemistry, v. 41, n. 5, p. 1160-1164, 2006.

CAMU, N, DE WINTER, T, VERBRUGGHE, $\mathrm{K}$, CLEENWERCK, I, VANDAMME, $\mathrm{P}$, TAKRAMA, JS, et al. Dynamics and biodiversity of populations of lactic acid bacteriaand acetic acid bacteria involved in spontaneous heap fermentation of cocoabeans in Ghana. Applied and nvironmental Microbiology, v. 73, n. 6, p. 1809-1824, 2007.

CHANPRASARTSUK, O. PRAKITCHAIWATTANAA, C., SANGUANDEEKULA, R., FLEET, G. Autochthonous yeasts associated with mature pineapple fruits, freshly crushed juice and their ferments; and the chemical changes during 
natural fermentation. Bioresource Technology. v. 101, n. 19, p. 7500-7509, 2010.

CLEENWERCK, I, DE VOS, P. Polyphasic taxonomy of acetic acid bacteria: anoverview of the currently applied methodology. International Journal of FoodMicrobiology 125 2-14, 2008.

DAMJANOVICT,V, CONNOLLY, CM, VAN SAENET, HKF, COOKEL, RWI , CORKILL, JE, VAN BELKUM, A, VAN VELZEN, D, Selective decontamination with nystatin for control of a Candida outbreak in a neonatal intensive care unit. Journal of Hospital Injection. v. 24, n. 4, p. 245-259, 1993.

DE VERO, L, GIUDICI, P, Genus-specific profile of acetic acid bacteria by $16 \mathrm{SrDNA}$ PCR-DGGE. International Journal of Food Microbiology. V. 125, n. 1, p. 96-101, 2008.

FLEET, GH, HEARD, GM, Yeasts: growth during fermentation. In: Fleet, G.H. (Ed.), Wine Microbiology and Biotechnology. Taylor and Francis, London, 27-54, 1993.

FREGAPANE. G, RUBIO-FERNÁNDEZ. H, SALVADOR, MD, Influence of fermentation temperature on semi-continuous acetification for wine vinegar production. Eur Food Res Technol. V. 213, n. 1, p. 62-66, 2001.

GONZALEZ, A, GUILLAMON, JM., MAS, A, POBLET, M, Application of molecularmethods for routine identification of acetic acid bacteria. International Journal ofFood Microbiology, v. 108, n. 1, p. 141-146, 2006.

GONZALEZ, A, HIERRO, N, POBLET, M, MAS, A, GUILLAMON, JM, Application ofmolecular methods to demonstrate species and strain evolution of acetic acidbacteria population during wine production. International Journal of Food Microbiology, v. 102, n. 2, p. 295-304, 2005.

GULlO, M, CAGGIA, C, DE VERO, L, GIUDICI, $\mathrm{P}$, Characterization of acetic acidbacteria in "traditional balsamic vinegar". International Journal of Food Microbiology v. 106, n. 2, p; 209-212, 2006.
GULLO, M, GIUDICI, P, Acetic acid bacteria in traditional balsamic vinegar: phenotypic traits relevant for starter cultures selection. International Journal of Food Microbiology v. 125, n. 1, p. 46-53, 2008.

HIDALGO, C, MATEO, E, MAS, A TORIJA, MJ, Identification of yeast and acetic acid bacteria isolated from the fermentation and acetification of persimmon (Diospyros kaki). Food Microbiology, v. 30, n. 1, p. 98 -104, 2012.

HOLT, JM, KRIEG, NR., SNEATH, PHA., STALEY, JY, WILLIAMS, ST, GenusAcetobacter and Gluconobacter. In Bergey's manual of determinative bacteriology 9th ed. p.71-84. Maryland, U.S.A: Williams \& Wilkens, 1994.

IVORRA C, PERREZ-ORTIN J E, OLMO M. $\mathrm{Na}$ inverse correlation between stress resistence and stuck fermentations in wine yeasts. A molecular study. Biotechnology and Bioengineering, v. 64, n. 6, p. 698-708, 1999. JARVIS, RW, Epidemiology of nosocomial fungal infections, with emphasis on candida species. Clin Infec Dis. v. 20, n. 6, p. 15261530, 1995.

JOHNSON, GH, DDS, TAYLOR, TD, HELD, DW, Clinical evaluation of a nystatin pastille for treatment ofdenture-related oral candidiasis. The Journal of Prosthetic Dentistry v. 61, n. 6, p. 699-703, 1989.

MILLET, V, LONVAUD-FUNEL, A, The viable but non-culturable state of winemicroorganisms during storage. Letters in Applied Microbiology v. 30, n. 2, p. 136-141, 2000.

NDOYE, B, LEBECQUE, S, DUBOISDAUPHIN, R, TOUNKARA, L, GUIRO, AT., KERE, C, DIAWARA, B, THONART, P, Thermoresistant properties of acetic acids bacteria isolated from tropicalproducts of SubSaharan Africa and destined to industrial vinegar. Enzyme and Microbial Technology v. 39, n. 4, p. 916-923, 2006.

SEEARUNRUANGCHAI, A, TANASUPAWAT, $\mathrm{S}$, KEERATIPIBUL, $\mathrm{S}$, THAW AI, C, ITOH, T, YAMADA, Y, Identification of acetic acid bacteria isolated 
from fruitscollected in Thailand. The Journal of General and Applied Microbiology v. 50, n. 1, p. 47-53, 2004.

SENGUN, IY, KARABIYIKLI, S. Importance of acetic acid bacteria in food industry. Review. Food Control v. 22, n. 5, p. 647-656, 2011. SOKOLLEK, SJ, HERTEL, C, HAMMES, WP. Cultivation and preservation ofvinegar bacteria. Journal of Biotechnology v. 60, n. 30, p. 195206, 1998.

SWINGS, J, The genera Acetobacter and Gluconobacter. In A. Balows,H. G. Trüper, M. Dworkin, W. Harder, \& K.-H. Schleifer (Eds.), The prokaryotes $\left(2_{\text {nd }}\right.$ ed.). (pp. 2268-2286) New York, NY: Springer-Verlag, 1992.

TORIJA, C, MATEO, E, GUILLAMON, JM, MAS, A, Identification and quantificationof acetic acid bacteria in wine and vinegar by Taq Man-MGB probes. Food Microbiology v. 27, n. 2, p. 257-265. 2010.

VITAL, TM, REIS, C., ZAPATA, MTAG, CUNHA, LC, Estudo comparativo de duas técnicas farmacopéicas de avaliação da atividade antimicrobiana dos fármacos: nistatina, eritromicina, neomicina e gentamicina. Braz J Pharm Sci v. 40, p. 19-227, 2004.

WEENK, G, OLIJVE, W, HARDER, W, Ketogluconate formation by Gluconobacterspecies. Applied Microbiology and Biotechnology v. 20, n. 6, p. 400-405, 1984.

VOS, P, GARRITY, G, JONES, D, KRIEG, NR, LUDWIG, W (ed.). Bergey's manual of systematic bacteriology. V.3. Baltimore: Williams \& Wilkins. Baltimore, Maryland. USA. 2009.

YAMADA, Y, HOSONO, R, LISDYANTI, P, WIDYASTUTI, Y, SAONO, S, UCHIMURA, $\mathrm{T}$, et al., Identification of acetic acid bacteria isolated from Indonesian sources,especially of isolates classified in the genus Gluconobacter. Journal of General and Applied Microbiology v. 45, n. 1, p. 23-28, 1999.

YAMADA, Y, YUKPHAN, P. Genera and species in acetic acid bacteria.International
Journal of Food Microbiology, v. 125, n. 1, p. 15-24, 2008.

YUKPHAN, P, MALIMAS, T, MURAMATSU, Y, TAKAHASHI, M, KANEYASU, M, POTACHAROEN, W., et al. Ameyamaea chiangmaiensis gen. nov., an aceticacid bacterium in the a-Proteobacteria. Bioscience Biotechnology Biochemistry v. 73, n. 10, p. 2156-2162, 2009.

YUKPHAN, P, MALIMAS, T, MURAMATSU, Y, TAKAHASHI, M, KANEYASU, M,TANASUPAWAT, $S$, et al. Tanticharoenia sakaeratensis gen. nov., sp. nov., a new osmotolerant acetic acid bacterium in the aProteobacteria. Bioscience Biotechnology Biochemistry v. 72, n. 3, p. 672-676, 2008.

ZAHOOR, T, SIDDIQUE, F, FAROOQ, U, Isolation and characterization of vinegarculture (Acetobacter aceti) from indigenous sources. British Food Journal v. 108, n. 6, p. 429-439, 2006.
Recebido: $13 / 08 / 2013$

Received: 08/13/2013

Aprovado: 27/10/2013

Approved: 10/27/2013 